\title{
Rozważania na temat represyjnych i prewencyjnych elementów odpowiedzialności odszkodowawczej na przykładzie instytucji odszkodowania karnego (punitive damages) w świetle orzeczenia Sądu Najwyższego oraz Trybunału Konstytucyjnego
}

\section{Wprowadzenie}

Problem sprawiedliwego określenia zobowiązania do naprawienia szkody od samego początku istnienia norm prawnych stanowił przedmiot licznych rozważań. Z początku naprawienie szkody było ściśle związane z represją za niewłaściwe zachowanie się dłużnika, z czasem jednak zaczęła przeważać idea nakazująca jedynie ( $w$ ramach szeroko pojętego prawa prywatnego) naprawienie szkody, tj. przywrócenie składników majątkowych poszkodowanego do takiego stanu, jaki istniałby, gdyby szkody nie wyrządzono. Idea ta jest ściśle związana z funkcją kompensacyjną odpowiedzialności odszkodowawczej i znajduje zasadniczo odzwierciedlenie w polskim systemie prawnym. Na gruncie innych porządków prawnych, a mianowicie w systemach common law, dopuszczalne jest jednak w szczególnych wypadkach zasądzenie punitive damages, czyli tzw. odszkodowania karnego, które spełnia głównie funkcję represyjną i prewencyjną. Jest to rozwiązanie wysoce kontrowersyjne w odniesieniu do założeń prawa polskiego w zakresie odpowiedzialności odszkodowawczej. W polskim prawie cywilnym, podobnie jak w wielu innych systemach prawnych (np. niemieckim), funkcja kompensacyjna jest bowiem podstawową funkcją odpowiedzialności odszkodowawczej. 
Stanowi ona także realny wyznacznik sposobu naprawienia szkody i wysokości odszkodowania.

W tym kontekście warto więc zastanowić się, co dokładnie należy rozumieć przez kompensację szkody i ewentualnie jakie są dopuszczalne odstępstwa od tej zasady. W ostatnich latach istotną rolę w rozumieniu funkcji kompensacyjnej odpowiedzialności odszkodowawczej w odniesieniu do instytucji odszkodowania karnego odegrał Sąd Najwyższy i Trybunał Konstytucyjny. Niniejsze opracowanie ukazuje wpływ istotnych, a nawet precedensowych orzeczeń w tym zakresie, tj. postanowienia Sądu Najwyższego z dnia 11 października 2013 r. (sygn. I CSK 697/12) ${ }^{1}$ oraz wyroku Trybunału Konstytucyjnego z dnia 23 czerwca 2015 r. (sygn. SK 32/14)2. Prezentowany tekst stanowi próbę zdefiniowania odszkodowania karnego na podstawie przytoczonych orzeczeń oraz próbę odpowiedzi na pytanie, czy w polskim systemie prawnym przewidziane są rozwiązania dopuszczające swego rodzaju odszkodowanie karne, a także jak instytucja ta wpływa na rozumienie odpowiedzialności odszkodowawczej w Polsce. W tym kontekście godna rozważenia jest również użyteczność tytułowego rozwiązania, wskazanie jego podstawowych założeń oraz ewentualnych alternatyw, które mogą prowadzić do osiągnięcia podobnych rezultatów.

\section{Definicja odszkodowania karnego w świetle orzeczenia I CSK 697/12; możliwość stwierdzenia wykonalności orzeczenia zasądzającego punitive damages}

Kluczowe znaczenie dla zrozumienia instytucji punitive damages $\mathrm{w}$ odniesieniu do prawa polskiego ma postanowienie Sądu Najwyższego z dnia 11 października 2013 r. (sygn. I CSK 697/12). Wskazując pokrótce istotne elementy dotyczące wskazanego orzeczenia, przytoczyć należy, że dotyczyło ono m.in. możliwości stwierdzenia wykonalności wyroku sądowego Sądu Obwodowego Hrabstwa C., Stanu I., z dnia 23 lipca 2009 r. (sąd Stanów Zjednoczonych). Wskazany wyrok zasądzał na rzecz powodów odszkodowanie za "udowodnione szkody” (actual

\footnotetext{
${ }^{1}$ Postanowienie Sądu Najwyższego (SN) z 11 X 2013 r., sygn. I CSK 697/12, Legalis nr 741884.

${ }^{2}$ Wyrok Trybunału Konstytucyjnego z 23 VI 2015 r., sygn. SK 32/14, Legalis nr 1259986.
} 
damages) w łącznej wysokości 1000000 dolarów oraz odszkodowanie karne (punitive damages) w wysokości 4000000 dolarów. Został on wydany w związku z opublikowaniem przez pozwanego materiału, który zarzucał powodom nadużycia podatkowe i finansowe w Polsce i Stanach Zjednoczonych, które dotyczyły obrotu papierami wartościowymi. Powodowie uzyskali określone wyżej odszkodowanie z tytułu naruszenia ich czci (defamation). W niniejszej sprawie Sąd Najwyższy uznał stwierdzenie wykonalności wyroku przyznającego odszkodowanie karne (punitive damages) za niedopuszczalne; dodatkowo wskazał na możliwość zmniejszenia odszkodowania stanowiącego w niniejszej sprawie zadośćuczynienie (actual damages).

Mimo że rozpatrywana sprawa dotyczyła w przeważającej mierze prawa międzynarodowego prywatnego, refleksja Sądu Najwyższego stanowi bardzo istotny głos w dyskusji dotyczącej sposobu rozumienia funkcji odpowiedzialności odszkodowawczej w polskim systemie prawnym, szczególnie w kontekście instytucji odszkodowania karnego. Sąd Najwyższy, rozpatrując wskazaną sprawę, musiał precyzyjnie określić podstawowe zasady polskiego porządku prawnego (w myśl prawa międzynarodowego prywatnego) oraz rozpatrzyć kompensacyjny charakter odszkodowania w kontekście konstytucyjnej zasady proporcjonalności. Dla stwierdzenia wykonalności wyroku państwa obcego konieczne jest m.in. to, by był on wykonalny w państwie wydania, oraz to, że nie zostały ustalone przeszkody w stwierdzeniu wykonalności tego orzeczenia, określone w art. 1146 Kodeksu postępowania cywilnego ${ }^{3}$. Sprzeczność wykonania zagranicznego orzeczenia z podstawowymi zasadami porządku prawnego stanowi taką przeszkodę.

Dla lepszego zrozumienia problematyki poruszanej w niniejszym artykule warto przytoczyć syntetyczną definicję punitive damages wskazaną w omawianym orzeczeniu. Punitive damages jest to wywodzące się z systemów common law odszkodowanie (świadczenie) przyznawane poszkodowanym dodatkowo, w wyjątkowych sytuacjach, jako wyraz moralnej krytyki zachowania sprawcy czynu niedozwolonego, gdy odpowiedzialny podmiot działał w złej wierze, bezmyślnie, beztrosko, opresyjnie, lekkomyślnie lub rażąco niedbale. Świadczenie to ma na celu głównie ukaranie sprawcy szkody, równocześnie umożliwiając uzyskanie poszkodowanemu dodatkowej korzyści majątkowej.

${ }^{3}$ Ustawa z dnia 17 XI 1964 r. Kodeks postępowania cywilnego (tekst jedn. Dz.U. 2016, poz. 1822), dalej „k.p.c.”. 
Ponadto wskazać należy, że instytucja ta dopuszczalna jest na gruncie odpowiedzialności deliktowej (intentional tort) lub odpowiedzialności za produkt. Rozwiązanie to nie jest zasadniczo stosowane na gruncie odpowiedzialności kontraktowej ${ }^{4}$. Punitive damages są uznawane za inną kategorię odszkodowania niż actual damages (które w prawie polskim można by było określić po prostu jako odszkodowanie); są z reguły zasądzane w przypadku przyznania actual damages, choć znane są sytuacje przyznawania ich osobno, nawet przy braku actual damages ${ }^{5}$.

Założeniem odszkodowania karnego ma być zasadniczo ukaranie sprawców szkody za ich działanie i "krzywdę" wyrządzoną społeczeństwu $^{6}$. Punitive damages zostały ustanowione głównie przez case law, które wyznacza jej zakres i przesłanki zastosowania ${ }^{7}$. W tym miejscu wskazać należy, że z konieczności definicja przywołana w niniejszym artykule została przedstawiona $\mathrm{w}$ formie daleko uproszczonej, ponieważ instytucja ta wywodzi się głównie z orzeczeń o precedensowym charakterze, niejednolite jest również rozumienie tej instytucji w poszczególnych państwach stosujących to rozwiązanie. Ponieważ jednak celem niniejszego opracowania jest głównie analiza stosunku prawa polskiego do punitive damages (jako instytucji preferującej funkcję represyjną i prewencyjną odszkodowania przed funkcją kompensacyjną), można zasadnie przyjąć, że wystarczające jest wskazanie tylko jej podstawowych założeń i zarysu. Można bowiem stwierdzić, że z punktu widzenia prawa polskiego nie są istotne szczegółowe rozważania na temat wszelkich różnic przyjętych w poszczególnych krajach (czy nawet stanach) lub kazuistyczna analiza przypadków, w których zasądzono punitive damages. Na marginesie zaznaczyć należy - choć jest to dosyć oczywiste - że odszkodowanie w prawie polskim również pełni funkcję prewencyjną oraz represyjną. Represja sprowadza się jednak do nałożenia na osobę wyrządzającą szkodę obowiązku jej naprawienia, co samo w sobie stanowi pewną dolegliwość. Naprawienie szkody

${ }^{4}$ M. Tolani, U.S. Punitive Damages Before German Courts: A Comparative Analysis with Respect to the Ordre Public, "Annual Survey of International \& Comparative Law" 2011, vol. 17 , no. 1 , s. 187.

${ }^{5}$ Ibidem, s. 188.

${ }^{6}$ Th. Colby, Beyond the Multiple Punishment Problem: Punitive Damages as Punishment for Individual, Private Wrongs, „Minnesota Law Review” 2003, vol. 87, s. 589.

${ }^{7}$ Por. Orzeczenie Sądu w stanie New Mexico z 18 VIII 1994 r. w sprawie Stella Liebeck v. McDonald's Restaurants, P.T.S., Inc. and McDonald's International, Inc. Nr. D-202 CV-93-02419, 1995 WL 360309; Orzeczenie Sądu Najwyższego USA z 20 V 1996 r. w sprawie BMW of N. Am., Inc. v. Gore, Nr 94-896 (517 U.S. 559). 
poprzez świadczenie z własnego majątku działa także prewencyjnie ${ }^{8}$. Pod uwagę warto brać również i to, że w Polsce przed transformacją ustrojową dość silnie manifestowany był pogląd o prymacie funkcji prewencyjnej odpowiedzialności odszkodowawczej, która mogła uzasadniać ograniczenie kompensacyjnego jej charakteru ${ }^{9}$. Stwierdzenie to obecnie wydaje się raczej nieaktualne, sama funkcja prewencyjna i wychowawcza wydają się uzasadnione wyłącznie w przypadku odpowiedzialności na zasadzie winy ${ }^{10}$.

Sąd Najwyższy w przytoczonym orzeczeniu I CSK 697/12, odnosząc się do możliwości wykonania orzeczenia przyznającego punitive damages, uznał kompensacyjny charakter odpowiedzialności odszkodowawczej za jedną z podstawowych zasad porządku prawnego, pozostającą $\mathrm{w}$ ścisłym związku z zasadą proporcjonalności wyrażoną w konstytucji (art. 31 ust. 3 w zw. z art. 2 Konstytucji Rzeczypospolitej Polskiej ${ }^{11}$ ). Sąd Najwyższy uznał przy tym, że naczelne zasady poszczególnych dziedzin prawa stanowią również podstawowe zasady porządku prawnego ${ }^{12}$. W orzeczeniu przytoczono także wcześniejsze wyroki sądów wskazujące, iż odszkodowanie - jako naprawienie szkody - nie może przewyższać co do zasady wysokości szkody, również w przypadku naprawienia szkody niemajątkowej ${ }^{13}$. Jak wskazano w orzeczeniu, jednym $z$ systemowych założeń prawa polskiego jest, aby środki cywilnoprawne skierowane przeciwko sprawcy szkody były proporcjonalne w rozumieniu prawa konstytucyjnego. Odstępstwa od przyjętej w prawie cywilnym zasady, że odszkodowanie służy kompensacji szkody i nie może przewyższać rozmiaru szkody, są zatem do zaakceptowania z punktu widzenia polskiego porządku prawnego tylko o tyle, o ile nie naruszają konstytucyjnej zasady proporcjonalności. Sąd Najwyższy wskazał również, że funkcja represyjna i prewencyjna stanowią jedynie pochodną funkcji

${ }^{8}$ Z. Radwański, A. Olejniczak, Zobowiązania - część ogólna, Warszawa 2006, s. 97.

${ }_{9}^{9}$ W. Warkałło, Odpowiedzialność odszkodowawcza: funkcje, rodzaje, granice, Warszawa 1972, s. 228.

${ }^{10}$ A. Szpunar, Odszkodowanie za szkodę majątkowa. Szkoda na mieniu i osobie, Bydgoszcz 1998, s. 133.

${ }^{11}$ Konstytucja Rzeczypospolitej Polskiej z dnia 2 IV 1997 r. (Dz.U. Nr 78, poz. 483 ze zm.), dalej „Konstytucja RP”.

${ }^{12}$ Por. postanowienie SN z 26 VI 1968 r., sygn. II CZ 118/68, Legalis nr 13592; uchwała SN z 22 VI 1972 r., sygn. III CZP 34/72, Legalis nr 16330; postanowienie SN z 21 IV 1978 r., sygn. IV CR 65/78, Legalis nr 20832; postanowienie SN z 26 II 2003 r., sygn. II CK 13/03, Legalis nr 58256; postanowienie SN z 9 III 2004 r., sygn. I CK 412/03, Legalis nr 80968.

${ }^{13}$ Postanowienie SN z 24 II 2006 r., sygn. III CZP 91/05, Legalis nr 106097; wyrok SN z 9 IX 2010 r., sygn. I CSK 689/09, Legalis nr 398012. 
kompensacyjnej, której zachowanie poprzez ograniczenie odszkodowania do rozmiaru szkody harmonizuje z zasadą proporcjonalności. W konsekwencji dopuszczenie wyroku przyznającego odszkodowanie w tak dużej wysokości musiałoby wiązać się z destabilizacją systemu odpowiedzialności odszkodowawczej w Polsce. Dodatkowo wskazać należy, że świadczenie na rzecz poszkodowanego w wysokości przekraczającej faktycznie doznaną szkodę jedynie w celach represyjnych i prewencyjnych wkraczałoby w sposób nieuzasadniony w dziedzinę prawa karnego i byłoby środkiem nieadekwatnym.

Ponadto wskazać należy, co podkreślono również w omawianym orzeczeniu, że punitive damages same $\mathrm{w}$ sobie nie stanowią rozwiązania sprzecznego z podstawowymi zasadami porządku prawnego (jako że podstawą zastosowania klauzuli porządku publicznego nie jest odmienność prawa obcego, ale sprzeczność skutków wiążących się z zastosowaniem obcego prawa ${ }^{14}$ ). Teoretycznie może to prowadzić do wniosku, że w pewnej sytuacji orzeczenie przyznające punitive damages mogłoby zostać uznane za wykonalne w Polsce, choć sytuacja ta - biorąc pod uwagę represyjny charakter wykraczający poza kompensację szkody - jest raczej nieprawdopodobna. Niemniej jednak częściowe przyznanie wykonalności odszkodowaniu karnemu mogłoby być możliwe ze względu na określone różnice systemów prawnych (np. zaliczenie pewnej części odszkodowania karnego na poczet kosztów procesu, które $\mathrm{w}$ systemach common law nie są $\mathrm{z}$ reguły przyznawane stronie wygrywającej proces).

Wskazane orzeczenie spotkało się z aprobatą przedstawicieli doktryny. Podkreśla się przede wszystkim jego precedensowy charakter w kontekście zastosowania klauzuli porządku publicznego ${ }^{15}$. Wydaje się, że ma ono kluczowe znaczenie dla rozumienia funkcji kompensacyjnej odpowiedzialności odszkodowawczej. W sposób klarowny porządkuje ono obecne rozważania dotyczące odpowiedzialności odszkodowawczej, szczególnie w zakresie ograniczenia odszkodowania. Wskazuje ono również, że sposób rozumienia kompensacji jest na tyle istotny, iż niedopuszczalne jest nawet pośrednie zaakceptowanie innych rozwiązań poprzez dopuszczenie orzeczeń innych państw. Można powiedzieć, że orzeczenie

${ }^{14}$ Por. postanowienie SN z 11 X 1974 r., sygn. II CR 735/74, OSPiKA 1976, nr 7, poz. 142.

${ }^{15}$ S. Sołtysiński, Glosa do wyroku SN z dnia 11 października 2013 r., I CSK 697/12, „Polski Proces Cywilny" 2014, nr 3; M. Orecki, Glosa do wyroku SN z dnia 11 października 2013 r., I CSK 697/12, OSP 2014, nr 9. 
to wpasowuje się w swego rodzaju "kontynentalną linię orzeczniczą"16, która - pomijając pewne różnice - nie dopuszcza do „erozji” rozumienia funkcji kompensacyjnej poprzez odmowę wykonalności punitive damages. Wskazane orzeczenie, pomimo swego międzynarodowego charakteru, jest często cytowane w orzeczeniach dotyczących sporów krajowych ${ }^{17}$.

\section{Wyrok Trybunału Konstytucyjnego SK 32/14 a konstytucyjność odszkodowania karnego}

Z opisanym powyżej orzeczeniem, w kontekście rozważań na temat punitive damages w odniesieniu do prawa polskiego, koresponduje wskazany wyrok Trybunału Konstytucyjnego. Trybunał Konstytucyjny uznał w jego sentencji za niekonstytucyjny art. 79 ust. 1 pkt 3 lit. b Ustawy $\mathrm{z}$ dnia 4 lutego 1994 r. o prawie autorskim i prawach pokrewnych ${ }^{18}$ w zakresie, w jakim uprawniony, którego autorskie prawa majątkowe zostały naruszone, może żądać od osoby, która naruszyła te prawa, naprawienia wyrządzonej szkody poprzez zapłatę sumy pieniężnej w wysokości odpowiadającej - w przypadku gdy naruszenie jest zawinione - trzykrotności stosownego wynagrodzenia, które w chwili jego dochodzenia byłoby należne $z$ tytułu udzielenia przez uprawnionego zgody na korzystanie $z$ utworu. Wskazany przepis został uznany za niezgodny z art. 64 ust. 1 i 2 w zw. z art. 31 ust. 3 w zw. z art. 2 Konstytucji RP.

Trybunał w przywoływanym wyroku dokonał dogłębnej analizy istoty prawa autorskiego i sposobów ochrony przed jego naruszeniami w kontekście odpowiedzialności odszkodowawczej. Przytoczone w nim zostały

${ }^{16}$ Wyrok niemieckiego Federalnego Sądu Najwyższego z 4 VI 1992 r., IX ZR 149/91, http://www.servat.unibe.ch/dfr/bz118312.html (dostęp: 27 II 2017); wyrok francuskiego Sądu Najwyższego w sprawie Fountaine Pajot z 1 XII 2010 r., nr 1090, https://www. courdecassation.fr/jurisprudence_2/premiere_chambre_civile_568/1090_1_18234.html (dostęp: 27 II 2017); wyrok Sądu Włoskiego w sprawie Parrot v. Fimez s.p.A, w: F. Quarta, Recognition and Enforcement of U.S. Punitive Damages Awards in Continental Europe: The Italian Supreme Court's Veto, "Hastings International and Comparative Law Review” 2008, vol. 31.

${ }^{17}$ Por. wyrok Sądu Apelacyjnego (SA) w Krakowie z 25 IX 2015 r., sygn. I ACa 780/15, Legalis nr 1360851; wyrok SA w Łodzi z 8 XII 2015 r., sygn. I ACa 815/15, Legalis nr 1408611; wyrok SN z 17 IV 2015 r., sygn. III CSK 173/14, Legalis nr 1263234; wyrok SN z 13 II 2014 r., sygn. V CSK 45/13, Legalis nr 993320; wyrok Krajowej Izby Odwoławczej z 25 IX 2014 r., sygn. KIO 1878/14, Legalis nr 1157702.

18 Tekst jedn. Dz.U. 2006 Nr 90, poz. 631; por. Dz.U. 2006 Nr 94, poz. 658; Dz.U. 2006 Nr 121, poz. 843; Dz.U. 2007 Nr 99, poz. 662; Dz.U. 2007 Nr 181, poz. 1293; Dz.U. 2009 Nr 157, poz. 1241; Dz.U. 2010 Nr 152, poz. 1016 ze zm. 
poglądy przedstawicieli doktryny, a także krytyka niektórych rozwiązań odpowiedzialności odszkodowawczej w tym zakresie. Wątpliwości te były już zgłaszane na etapie prac legislacyjnych. Trybunał wskazał, co prawda, że w przypadku odszkodowania za naruszenie praw autorskich określenie szkody poniesionej przez dany podmiot może być znacznie utrudnione, co $\mathrm{w}$ pewnych sytuacjach uzasadnia przyjęcie rozwiązań w zakresie ułatwienia dochodzenia wskazanych roszczeń, nie mogą one jednak być całkowicie oderwane od wysokości szkody. Rozwiązanie polegające na przyznaniu w przypadku naruszenia praw autorskich trzykrotności stosownego wynagrodzenia może więc zostać przyrównane mutatis mutandis do punitive damages w systemach common law. Co ciekawe, wątpliwości odnośnie do wskazanego przepisu zostały już wyrażone w orzeczeniu Sądu Najwyższego w sprawie I CSK 697/12, a także w glosach go dotyczących ${ }^{19}$.

Trybunał Konstytucyjny stwierdził, że co do zasady, ustanowienie zryczałtowanego roszczenia odszkodowawczego nie stanowi samo w sobie naruszenia zasady proporcjonalności, przez której pryzmat badany był wskazany przepis. Ustanawiając jednak zryczałtowane odszkodowanie, niewymagające ustalenia wysokości szkody, a wręcz całkowicie od niej oderwane, ustawodawca naruszył równowagę pomiędzy pozycją obu podmiotów (Trybunał Konstytucyjny nie stwierdził przy tym, by na gruncie prawa autorskiego zasadne było wyróżnienie strony słabszej, jak w relacji konsument - przedsiębiorca, pracownik - pracodawca). Ponadto rozwiązanie to odrywa się także od zasady adekwatnego związku przyczynowego, nie dając przy tym sprawcy deliktu efektywnych instrumentów umożliwiających obronę i zminimalizowanie uszczerbku majątkowego. W ten sposób odszkodowanie może kilkakrotnie przewyższyć rozmiar szkody. W konsekwencji w uzasadnieniu wyroku uznano, że ustawodawca naruszył zasadę najłagodniejszego środka, dopuszczając się nadmiernej ingerencji w sferę praw majątkowych sprawcy naruszenia.

Biorąc pod uwagę powyższe, stwierdzić można, że wskazane orzeczenie wyeliminowało $\mathrm{z}$ polskiego systemu prawnego rozwiązanie przyznające potencjalnie możliwość odszkodowania przekraczającego wysokość poniesionej szkody, które odznacza się również charakterem represyjnym i prewencyjnym. Wydaje się przy tym, że wskazane rozwiązanie przyznaje nawet większą ochronę poszkodowanemu, gdyż nie ogranicza się - jak w przypadku punitive damages - do wyjątkowych, „karygodnych" przypadków rażącego naruszenia.

${ }^{19}$ M. Orecki, op. cit., s. 1212; S. Sołtysiński, op. cit., s. 415. 


\section{Potencjalne odstępstwa od kompensacyjnego charakteru odpowiedzialności odszkodowawczej w kierunku odszkodowania karnego}

Mimo wyeliminowania art. 79 ust. 1 pkt 3 lit. b z ustawy o prawie autorskim i prawach pokrewnych w zakresie możliwości przyznania trzykrotności należnego wynagrodzenia w przypadku zawinionego naruszenia otwarta pozostaje nadal kwestia konstytucyjności możliwej do uzyskania dwukrotności należnego wynagrodzenia należnego za korzystanie $\mathrm{z}$ utworu $\mathrm{w}$ przypadku niezawinionego naruszenia. Częściowo aktualne pozostaja bowiem uwagi poczynione w wyroku SK 32/14 co do uchylonego rozwiązania. Wydaje się przy tym, że zasądzenie dwukrotności wynagrodzenia może również doprowadzić do uzyskania odszkodowania przekraczającego rozmiar szkody. Niemniej jednak, porównując oba rozwiązania, należy stwierdzić, że przyznanie trzykrotności stosownego wynagrodzenia ewidentnie stanowi wyłom w stosunku do kompensacyjnego charakteru odpowiedzialności odszkodowawczej. Nie można bowiem uznać, iż zawinione naruszenie wiąże się z poniesieniem wyższej szkody niż w przypadku naruszenia niezawinionego. Zastosowanie takiego rozwiązania nie wydaje się również konieczne ze względu na treść dyrektywy 2004/48/WE ${ }^{20}$, która była podstawą ustanowienia wskazanego przepisu (choć można uznać, że możliwość taka została w niej przewidziana ${ }^{21}$ ). Oczywiście, szkoda poniesiona $w$ wyniku naruszenia praw autorskich może wykraczać poza samą utraconą korzyść (stosowne wynagrodzenie), nie należy bowiem ignorować argumentu, że trudności związane ze znalezieniem osoby odpowiedzialnej za naruszenie praw autorskich i skierowaniem sprawy na drogę sądową wiążą się ze sporymi kosztami ${ }^{22}$. Wydaje się jednak, iż nie powinno się a priori zakładać, że faktycznie poniesiona szkoda będzie chociażby zbliżona do dwukrotności stosownego wynagrodzenia.

W tym kontekście należy również zwrócić uwagę na to, że ochrona praw majątkowych może powodować konieczność modyfikacji zasad

${ }^{20}$ Dyrektywa 2004/48/WE Parlamentu Europejskiego i Rady z dnia 29 IV 2004 r. w sprawie egzekwowania praw własności intelektualnej z dnia 29 IV 2004 r. (Dz.Urz. UE L 157 z 30 IV 2004 r., s. 45).

${ }^{21}$ Por. A. Tischner, Harmonizacja prawa polskiego z wymogami dyrektywy w sprawie egzekwowania praw własności intelektualnej, cz. II, „Monitor Prawniczy” 2005, nr 14, s. 690.

${ }^{22}$ H. Koziol, Punitive Damages - A European Perspective "Louisiana Law Review” 2008, vol. 68 , no. 3 , s. 759 . 
odpowiedzialności ogólnie przyjętych i wprowadzania zasad szczególnych dla pewnych sytuacji ${ }^{23}$, lecz każdorazowe odejście od klasycznych zasad odpowiedzialności powinno być dokonywane ze świadomością wszystkich skutków takiej decyzji ${ }^{24}$. Wydaje się przy tym, iż w samej dyrektywie zaznaczono konieczność zastosowania adekwatnych środków i unikania odszkodowania o charakterze kary (zob. np. tezy 17 i 26 preambuły do dyrektywy). Przyjęte w prawie polskim rozwiązania mogłyby okazać się nawet sprzeczne $\mathrm{z}$ art. 3 dyrektywy, który stanowi, że nieprzekraczalną granicą dolegliwości środków prawnych wynikających z dyrektywy jest ich "słuszność i sprawiedliwość" ${ }^{25}$. Dodatkowo wskazać należy, iż rozwiązanie przyjęte w art. 79 ust. 1 pkt 3 lit. b (także w zakresie dwukrotności stosownego wynagrodzenia) nie koresponduje $\mathrm{z}$ rozwiązaniem przyjętym w art. 287 Ustawy z dnia 30 czerwca $2000 \mathrm{r}$. Prawo własności przemysłowej ${ }^{26}$, która w przypadku naruszenia przewiduje alternatywnie jedynie jednokrotność stosownej opłaty licencyjnej.

Analizując inne rozwiązania przyjęte w prawie polskim, można właściwie stwierdzić (co wskazane zostało również w orzeczeniu I CSK 697/12), że mimo ustanowienia pewnych ułatwień w sposobie dochodzenia odszkodowania pozostają one w zgodzie $\mathrm{z}$ kompensacyjnym charakterem odpowiedzialności odszkodowawczej (m.in. art. 446 § 3 Kodeksu cywilnego ${ }^{27}$, art. 394 k.c. i art. 481 k.c.; art. 322 k.p.c.; art. 50 Kodeksu pracy ${ }^{28}$, art. 58 k.p. i art. $47^{1}$ k.p. , art. 7 Rozporządzenia $261 / 2004^{29}$ ). W przypadku zadatku (art. 394 k.c.) czy też kary umownej (art. 481 k.c.)

${ }^{23}$ J. Błeszyński, Ochrona autorskich praw majątkowych, Warszawa 1989, s. 164.

${ }^{24}$ A. Tischner, Harmonizacja prawa polskiego ..., cz. II, s. 691.

${ }^{25}$ A. Tischner, Harmonizacja prawa polskiego z wymogami dyrektywy w sprawie egzekwowania praw własności intelektualnej, cz. I, „Monitor Prawniczy” 2005, nr 13, s. 633; por. wyrok Europejskiego Trybunału Sprawiedliwości z 10 IV 2014 r. w sprawie C-435/12, http://curia.europa.eu/juris/document/document.jsf;jsessionid=9ea7d2dc30d 5c5ee624c7db0466da105c848e5f973ed.e34KaxiLc3qMb40Rch0SaxyKchb0?text = \& docid $=150786 \&$ pageIndex $=0 \&$ doclang $=$ pl \& $\operatorname{mode}=1$ st $\&$ dir $=\&$ occ $=$ first $\&$ part $=$ $1 \&$ cid=1072392 (dostęp: 23 II 2017).

${ }^{26}$ Tekst jedn. Dz.U. 2013, poz. 1410.

${ }^{27}$ Ustawa dnia 23 IV 1964 r. Kodeks cywilny (tekst jedn. Dz.U. 2016, poz. 380), dalej „k.c.".

${ }^{28}$ Ustawa z dnia 26 VI 1974 r. Kodeks pracy (tekst jedn. Dz.U. 2016, poz. 1666), dalej "k.p.".

${ }^{29}$ Rozporządzenie (WE) nr 261/2004 Parlamentu Europejskiego i Rady z dnia 11 II 2004 r. ustanawiające wspólne zasady odszkodowania i pomocy dla pasażerów w przypadku odmowy przyjęcia na pokład albo odwołania lub dużego opóźnienia lotów, uchylające rozporządzenie (EWG) nr 295/91 z dnia 11 II 2004 r. (Dz.Urz. UE L 46 z 17 II 2004 r., s. 1). 
mamy do czynienia z wolą stron, co wydaje się samo w sobie pewnym usprawiedliwieniem ingerencji w prawa sprawcy szkody (podobnie w art. 473 k.c.). Odnośnie do zadatku wskazać można, że chociaż jego wysokość kreują reguły rządzące zasadą swobody kontraktowania, która została wyrażona przez ustawodawcę w treści art. $353^{1}$ k.c., to uznaje się, iż kwota ta winna stanowić „pewien ułamek - zwykle niewiel$\mathrm{ki}$ - świadczenia pieniężnego, które jedna ze stron ma spełnić" ${ }^{\prime \prime 3}$. Choć w orzecznictwie dostrzec można dość liberalne podejście do ustanowienia wysokości zadatku ${ }^{31}$, w razie ustalenia zadatku rażąco wysokiego jego zatrzymanie lub żądanie zwrotu sumy dwukrotnie wyższej może być uznane za nadużycie prawa ${ }^{32}$. Analizując natomiast pokrótce instytucję kary umownej, wydaje się, że należałoby jej przyznać prymat funkcji kompensacyjnej, a jej oddziaływanie przymuszające i represyjne uznać jedynie za skutek wtórny ${ }^{33}$. Kara umowna o rażącej wysokości oraz wyłącznie w celu wywarcia presji psychicznej na dłużnika podlegać może bowiem miarkowaniu, co ogranicza jej represyjny walor. Inaczej byłoby, gdyby ustawodawca nie przewidział możliwości jej miarkowania lub umożliwił wyłączenie miarkowania kary umownej w drodze umowy ${ }^{34}$. Przytoczyć można więc pogląd, że kara umowna pełni funkcję zabezpieczającą wykonanie zobowiązań kontraktowych, a w wypadku niewykonania lub nienależytego wykonania tych zobowiązań - funkcję kompensacyjna, ułatwiając uzyskanie odszkodowania ${ }^{35}$.

Zgodzić należałoby się również ze stwierdzeniem Sądu Najwyższego oraz Trybunału Konstytucyjnego wyrażonym w referowanych orzeczeniach, że przyznanie odpowiedniej kwoty w ramach odszkodowania (odszkodowanie zryczałtowane), które ma z założenia stanowić kompensację szkody, jest dopuszczalne, o ile nie jest oderwane od wysokości szkody. W pewnych wypadkach może ono mieć również związek z uprzywilejowaniem strony słabszej. Wydaje się przy tym, że wskazana granica nie jest oczywista, jednakże niezwykle pomocne wydaje się zastosowanie testu proporcjonalności. Podając za przykład

\footnotetext{
${ }^{30}$ J. Gwiazdomorski, Glosa do uchwaty SN z 10.10.1961 r., 3 CO 28/61, OSPiKA 1963, nr 5, poz. 107.

${ }^{31}$ Wyrok SN z 13 II 2002 r., sygn. IV CKN 672/00, Legalis nr 54589.

${ }^{32}$ Wyrok SN z 13 II 2002 r., sygn. IV CKN 672/00.

${ }^{33}$ Wyrok SA w Szczecinie z 23 IX 2014 r., sygn. I ACa 347/14, Legalis nr 1241422.

${ }^{34}$ Kodeks cywilny. Komentarz, pod red. K. Osajdy, Warszawa 2017, komentarz do art. 483.

${ }^{35}$ J. Rajski, W. Kocot, K. Zaradkiewicz, Prawo kontraktów handlowych, Warszawa 2007, s. 305 .
} 
art. 788 k.c., stwierdzić można, że nie jest sprzeczne z podstawowymi zasadami odpowiedzialności odszkodowawczej usunięcie w niektórych przypadkach pewnych granic w wysokości zasądzonego odszkodowania w przypadku umyślnego naruszenia (w konsekwencji dochodzi bowiem jedynie do pełniejszej kompensacji, a nie jej przekroczenia w celach represyjnych). Adekwatne wydaje się bowiem stwierdzenie, że funkcja kompensacyjna realizuje potrzebę przeniesienia ciężaru szkody doznanej przez poszkodowanego na inny podmiot, gdy w społecznej ocenie moralnej nie byłoby zasadne obciążenie nią samego poszkodowanego $^{36}$. Wskazany przykładowo art. 788 k.c. stanowi więc rozwiązanie, w którym wina ma wpływ na rozmiar odszkodowania, nie powinno to być jednak uznane za niespójne z podstawowymi założeniami odpowiedzialności odszkodowawczej. Ustawodawca przyjął - co nie zdaje się sprzeczne z konstytucyjną zasadą proporcjonalności - że dopuszczalne jest pewne zaostrzenie odpowiedzialności odszkodowawczej w przypadku zawinionej szkody. Jest to jednak rozwiązanie wyważone, gdyż nie ma na celu umożliwienia uzyskania odszkodowania przewyższającego szkodę, ale jedynie usuwa ograniczenie odpowiedzialności. Analogicznie, pewne ograniczenia wysokości odszkodowania z powodu niezawinionego naruszenia lub innych okoliczności (art. 440 k.c.) moga być w określonych sytuacjach zasadne, o ile mamy do czynienia tylko z ograniczeniem kompensacji, a nie przyznaniem pierwszeństwa represji i prewencji. Analiza poszczególnych przypadków zdaje się jednak umożliwiać twierdzenie, że nie wszystkie przepisy dotyczące odpowiedzialności odszkodowawczej konsekwentnie realizują kompensacyjny charakter odszkodowania i wskazane założenia właściwe dla tego rodzaju odpowiedzialności. Biorąc pod uwagę treść wyroku Trybunału Konstytucyjnego w sprawie SK 32/14, można bowiem zasugerować, że pewne przepisy, bazując na rozwiązaniu wręcz identycznym co w przypadku uznanego za niekonstytucyjny art. 79 ust. 1 pkt 3 lit. b ustawy o prawie autorskim i prawach pokrewnych, mogłyby również zostać uznane za niezgodne z Konstytucją RP. Chodzi mianowicie o art. 36a ust. 1 pkt 3 lit. b Ustawy z dnia 26 czerwca 2003 r. o ochronie prawnej odmian roślin ${ }^{37}$ oraz art. 11 ust. 1 pkt 3 lit. b Ustawy o ochronie baz danych z dnia 27 lipca $2001 \mathrm{r}^{38}$ We wskazanych przepisach również umożliwia się uzyskanie wielokrotności stosownej opłaty w przypadku

\footnotetext{
${ }^{36}$ W. Czachórski, Zarys prawa zobowiązań Część ogólna, Warszawa 1963, s. 90.

37 Tekst jedn. Dz.U. 2016, poz. 843.

${ }^{38}$ Tekst jedn. Dz.U. Nr 128, poz. 1402.
} 
zawinionego naruszenia. Uwzględniając powyższe, zasadna wydaje się rewizja wskazanych rozwiązań przez ustawodawcę pod kątem ich konstytucyjności.

\section{Analiza użyteczności punitive damages - potencjalne alternatywy w prawie polskim}

Choć analiza odszkodowania karnego pod kątem jego użyteczności nie stanowi tematu niniejszego opracowania, warto wspomnieć o podstawowych elementach przemawiających zarówno za tym rozwiązaniem, jak i przeciwko niemu. Ponownie należy jednak podkreślić, że analiza ta jest przeprowadzona w sposób uogólniony, traktujący punitive damages bardziej jako potencjalną inspirację do wprowadzenia zmian, a nie gotowy model.

Najbardziej oczywistą zaletą punitive damages jest stworzenie rozwiązania, które może efektywnie zapobiegać nadużyciom dokonywanym przez podmioty gospodarcze, dla których poniesienie uszczerbku poprzez samo wyrównanie szkody nie stanowi wystarczającej przestro$\mathrm{gi}^{39}$. Przyznanie znacznego odszkodowania (w szczególności większej liczbie poszkodowanych) może oznaczać realny uszczerbek dla danego podmiotu, który - mimo posiadania znacznych środków finansowych - będzie dla niego dotkliwy. Dodatkowo wskazać należy, że punitive damages kompensują też koszty procesu, które zasadniczo nie są przyznawane w prawie Stanów Zjednoczonych nawet w przypadku wygrania procesu ${ }^{40}$.

Przeciwko wskazanemu rozwiązaniu przemawia przede wszystkim to, że niektóre jego zalety nie mają znaczenia w prawie polskim, niemieckim, czy też ogólniej rzecz ujmując, w tzw. kontynentalnych systemach prawnych. W prawie polskim koszty procesu są bowiem zasadniczo przyznawane stronie wygrywającej, w przypadku szkody niemajątkowej możliwe jest przyznanie zadośćuczynienia ${ }^{41}$. Co więcej, element prewencyjny prawa karnego jest bardziej wyraźny w europejskich systemach prawnych niż w przypadku prawa amerykańskiego ${ }^{42}$.

${ }^{39}$ M. Tolani, op. cit., s. 191.

${ }^{40}$ H. Koziol, op. cit., s. 761.

${ }^{41}$ Por. E. Sonntag, Entwicklungstendenzen der Privatstrafen: Strafschadensersatz im antiken römischen, deutschen und US-amerikanischen Recht, Berlin 2005, s. 350.

${ }^{42}$ Ibidem, s. 348. 
Przeciwko temu rozwiązaniu przemawiają jednak przede wszystkim wątpliwości natury konstytucyjnej (podnoszone obecnie również przez przedstawicieli doktryny prawa Stanów Zjednoczonych $)^{43}$. Rozwiązanie to może też wywoływać trudne do przewidzenia skutki ${ }^{44}$. Z drugiej strony wskazać można, że prewencja w stosunku do dużych korporacji może być przynajmniej w pewnym stopniu realizowana na gruncie prawa publicznego poprzez zwalczanie nieuczciwych praktyk rynkowych, prawo karne czy sankcje wynikające $z$ innych przepisów. Ponadto należy brać pod uwagę, że punitive damages wkraczają w pewnym stopniu w domenę prawa karnego, nie dając jednak gwarancji przyznawanych oskarżonemu ${ }^{45}$.

Ujmując bowiem polski system prawny jako całość, nie można uznać, że prewencja i represja w przypadkach wyrządzenia innemu podmiotowi szkody nie jest realizowana w ramach innych dziedzin prawa. Nie sposób tego zagadnienia omówić w sposób kompleksowy w niniejszym opracowaniu (szczególnie uwzględniając ostatnie zmiany w tym zakresie), zaznaczyć jednak można, że w określonych przypadkach, korzystając z przepisów innych dziedzin prawa, możliwe jest uzyskanie kompensacji szkody przy „zwiększonej” prewencji i represji. Oczywistością jest, że wyrządzenie szkody może w określonych sytuacjach stanowić przestępstwo, które wiąże się z odpowiedzialnością karną i wymierzeniem sprawcy kary lub orzeczeniem w stosunku do niego środków karnych. Przestępstwo może bowiem stanowić czyn niedozwolony w myśl prawa cywilnego ${ }^{46}$. Brak, co prawda, całkowitej zgody odnośnie do określenia funkcji prawa karnego, ogólnie można jednak wskazać, że wyróżnia się funkcję sprawiedliwościową i ochronną (w ramach nich również prewencyjną i represyjną $)^{47}$. Za najważniejszą funkcję autorzy zdają się przyjmować funkcję ochronną, z którą związana jest funkcja prewencyjno-wychowawcza; funkcja sprawiedliwościowa wiąże się natomiast bezpośrednio z karą ${ }^{48}$. Szczególnie istotne znaczenie dla wskazanej problematyki mają przepisy dotyczące przestępstw przeciwko mieniu i przeciwko obrotowi gospodarczemu. W przypadku

${ }^{43}$ M. Tolani, op. cit., s. 192.

${ }^{44}$ H. Koziol, op. cit., s. 742.

${ }^{45}$ Ibidem, s. 753.

${ }^{46}$ A. Bulsiewicz, Zabezpieczenie roszczeń odszkodowawczych $i$ kar majątkowych w postępowaniu karnym, Toruń 1972, s. 17.

47 Por.: System prawa karnego. Zagadnienia ogólne, t. 1, pod red. A. Marka, Warszawa 2010, s. 12-13; L. Gardocki, Prawo karne, Warszawa 2015, s. 7-8.

48 System prawa karnego..., s. 18. 
wyrządzenia szkody przestępstwem, w ramach procesu karnego na podstawie art. 415 Kodeksu postępowania karnego ${ }^{49}$ oraz art. 46 i 47 Kodeksu karnego ${ }^{50}$ możliwe jest zarówno dochodzenie odszkodowania (naprawienia szkody, uzyskania nawiązki czy zadośćuczynienia), jak i wymierzenie określonemu podmiotowi kary (środka karnego). W doktrynie prawa karnego akcentuje się bowiem wzrost funkcji kompensacyjnej polskiego prawa karnego ${ }^{51}$, choć sporne jest znaczenie funkcji kompensacyjnej wspomnianych środków ${ }^{52}$. Można jednak uznać, że represja i prewencja mogą być znacznie skuteczniej realizowane na gruncie prawa publicznego. Wszak wskazuje się nawet, że nowoczesny wymiar sprawiedliwości zachowuje jako podstawowy punkt wyjścia zemstę ludu, a nowoczesna kara stanowi - podobnie jak u ludów pierwotnych - vindicta publica ${ }^{53}$. Niewątpliwie jednak, ukaranie sprawcy szkody w postępowaniu karnym nie wywołuje podobnych wątpliwości konstytucyjnych co w przypadku prawa cywilnego.

Na marginesie można również wskazać (uwzględniając wcześniejsze uwagi), że wyrządzenie szkody przez podmioty prowadzące działalność gospodarczą może także wiązać się w określonych przypadkach z zakazem wykonywania działalności gospodarczej lub z niemożnością prowadzenia konkretnej działalności ${ }^{54}$ (np. w przypadku cofnięcia koncesji). Działania powodujące szkodę mogą też wiązać się nieuczciwymi praktykami rynkowymi ${ }^{55}$ lub czynami nieuczciwej konkurencji ${ }^{56}$ (np. poprzez wprowadzenie w błąd co do jakości produktu).

${ }^{49}$ Ustawa z dnia 6 VI 1997 r. Kodeks postępowania karnego (tekst jedn. Dz.U. 2016, poz. 1749).

${ }^{50}$ Ustawa z dnia 6 VI 1997 r. Kodeks karny (tekst jedn. Dz.U. 2016, poz. 1137).

${ }^{51}$ Kodeks karny. Czesść ogólna, t. 1, cz. 1: Komentarz do art. 1-52, pod red. W. Wróbla, A. Zolla, Warszawa 2016, s. 893.

52 Por. Kodeks karny. Komentarz, pod red. R. Stefańskiego, Warszawa 2017, komentarz do art. 46; A. Pilch, Charakter obowiazku naprawienia szkody w trybie art. 46 KK a problemy praktyki orzeczniczej, w: Karnomaterialne i procesowe aspekty naprawienia szkody, pod red. Z. Ćwiąkalskiego, G. Artymiak, Warszawa 2010, s. 125.

${ }^{53} \mathrm{~J}$. Makarewicz, Wstep do filozofii prawa karnego w oparciu o podstawy historyczno-rozwojowe, tłum. K. Jakubów, red. nauk. A. Grześkowiak, Lublin 2009, s. 295.

${ }^{54}$ Por. M. Waligórski, Koncesje, zezwolenia i licencje w polskim administracyjnym prawie gospodarczym, Poznań 2012, s. 69-70; C. Kosikowski, Ustawa o swobodzie działalności gospodarczej. Komentarz, Warszawa 2013, s. 268-275; P. Wrześniewski, Ustawa o działalności gospodarczej. Komentarz, Warszawa 2010, s. 150-155.

${ }^{55}$ Ustawa z dnia 23 VIII 2007 r. o przeciwdziałaniu nieuczciwym praktykom rynkowym (tekst jedn. Dz.U. 2016, poz. 3).

${ }^{56}$ Ustawa z dnia 16 IV 1993 r. o zwalczaniu nieuczciwej konkurencji (tekst jedn. Dz.U. 2003 Nr 153, poz. 1503). 


\section{Podsumowanie}

Po dokonaniu analizy przedstawionej problematyki można stwierdzić, że prawo polskie zasadniczo realizuje założenie kompensacyjnego charakteru odszkodowania, natomiast większość odstępstw od tego założenia zmierza w kierunku ograniczenia odszkodowania. Nie sposób w tym kontekście pominąć jednak wskazanych rozwiązań, których konstytucyjność może zostać zakwestionowana (m.in. odszkodowanie przyznane $\mathrm{w}$ prawie autorskim, ustawie o ochronie baz danych, o ochronie prawnej odmian roślin) i które de facto wprowadzają pewną penalizację $e^{57}$. Wydaje się jednak, że aktualna pozostaje $w$ tym zakresie uwaga odnośnie do rozwiązań przewidzianych w prawie autorskim, iż pewne trudności związane $z$ uzasadnieniem sprzeczności kar cywilnych z polskim porządkiem publicznym (a w konsekwencji też z podstawowymi założeniami odpowiedzialności odszkodowawczej) wiążą się po prostu z kontrowersyjnymi decyzjami polskiego rządu i parlamentu ${ }^{58}$. Można więc zaryzykować twierdzenie, że te kontrowersyjne decyzje są raczej związane z pewną niekonsekwencją ustawodawcy, a niekoniecznie z próbą fundamentalnej zmiany rozumienia odpowiedzialności odszkodowawczej w prawie polskim. Abstrahując bowiem od pozytywów i negatywów instytucji odszkodowania karnego, wydaje się, że aby możliwe było jego wprowadzenie (a następnie zachowanie $\mathrm{w}$ systemie prawa polskiego $\mathrm{w}$ przypadku kontroli konstytucyjności), konieczna byłaby nie tylko zmiana poszczególnych ustaw, ale być może nawet Konstytucji RP lub przynajmniej rozumienia podstawowych zasad w niej wyrażonych. Po analizie argumentacji wskazanej przez Trybunał Konstytucyjny w orzeczeniu w sprawie SK 32/14 dopuszczalne wydaje się twierdzenie, że rozwiązania podobne do punitive damages moga zasadniczo tworzyć zbyt daleką dysproporcję w środkach cywilnoprawnych przyznanych stronom (poszkodowanemu i sprawcy szkody), co pozostaje w sprzeczności z konstytucyjną zasadą proporcjonalności.

$\mathrm{W}$ pełni należy zgodzić się $\mathrm{z}$ argumentacją przedstawioną $\mathrm{w}$ referowanych orzeczeniach. Wydaje się, że gdyby ich sentencje były inne,

${ }^{57}$ Analiza wskazanej kwestii w prawie niemieckim: V. Behr, Strafschadensersatz im deutschen Recht - Wiederauferstehung eines verdrängten Phänomens, "Zeitschrift für das Juristische Studium" 2010, Nr. 3, s. 292-296; N. Jansen, L. Rademacher, Punitive Damages in Germany, w: H. Koziol, V. Wilcox, Punitive Damages: Common Law and Civil Law Perspectives, Vienna 2009, s. 75-85.

${ }^{58}$ S. Sołtysiński, op. cit., s. 420. 
w polskim systemie prawnym mogłoby dojść do swoistej „erozji” kompensacyjnego charakteru odpowiedzialności odszkodowawczej. Biorąc jednak pod uwagę wcześniejsze spostrzeżenia, można stwierdzić, że pewne rozwiązania przyjęte w ustawodawstwie polskim wymagają zmiany. Wydaje się przy tym, iż sądy, podążając w dużej mierze za głosami doktryny, negatywnie odnoszą się do rozwiązań na kształt odszkodowania karnego; dotychczasowa linia orzecznicza $\mathrm{w}$ tym zakresie pozwala przyjąć, że w przyszłości również spodziewać się można wykładni przyznającej pierwszeństwo funkcji kompensacyjnej odszkodowania, a sprzeciwiającej się odszkodowaniom o charakterze karnym. Nie oznacza to jednak, na co wskazywano już wcześniej, że wina w żadnym wypadku nie ma i nie powinna mieć wpływu na wysokość odszkodowania. Nawet jednak wina umyślna po stronie sprawcy nie powinna umożliwiać uzyskania odszkodowania z założenia przekraczającego poniesioną szkodę (nie budzi jednak sprzeciwu rozwiązanie przyjęte np. w art. 788 k.c., o czym była mowa wcześniej). W przeciwnym razie odszkodowanie takie będzie pełnić przede wszystkim funkcję represyjną i prewencyjna, co wiąże się $\mathrm{z}$ wątpliwościami przedstawionymi w zaprezentowanym artykule.

Uznając jednak, że odpowiedzialność odszkodowawcza ma na celu przede wszystkim realizację idei sprawiedliwości ${ }^{59}$, przytoczyć można bardzo obrazową sentencję: „ «W erze atomu» przestają wystarczać typy odpowiedzialności odszkodowawczej "wieku pary i elektryczności»" ${ }^{\prime 60}$. Ewolucja rozumienia odpowiedzialności odszkodowawczej wydaje się więc nieunikniona, chociaż w dłuższej perspektywie ciężko jest wyrokować, w którą stronę się ona skieruje. Mimo wszystko należy pamiętać, że polski system prawny przewiduje, poza szeroko rozumianym prawem prywatnym, pewne rozwiązania realizujące funkcję represyjną i prewencyjną (o czym wspomniano wcześniej), które zastosowanie znaleźć mogą w przypadkach "karygodnego” wyrządzenia szkód.

Gdyby jednak ustawodawca zdecydował się na wprowadzenie swoistej kary prywatnej (kierując się np. ekonomią polityczną ${ }^{61}$ ), należy uwzględnić, że konieczne będzie zachowanie szczególnej ostrożności i balansu środków przyznanych stronom. W przypadku zapożyczania rozwiązań $z$ innych systemów prawnych zasadne wydaje się również uwzględnienie konsekwencji dla całego systemu prawnego w danym państwie.

${ }^{59}$ M. Kaliński, Szkoda na mieniu i jej naprawienie, w: System prawa prywatnego. Prawo zobowiazzań - część ogólna, t. 6, pod red. A. Olejniczaka, Warszawa 2014, s. 73.

${ }^{60}$ W. Warkałło, op. cit., s. 15.

${ }^{61}$ Por. A. Stelmachowski, Zarys teorii prawa cywilnego, Warszawa 1998, s. 53-61. 


\section{DELIBERATIONS ON THE PUNITIVE AND PREVENTIVE ELEMENTS OF THE LIABILITY FOR DAMAGES IN LIGHT OF THE RULINGS OF THE SUPREME COURT AND THE CONSTITUTIONAL TRIBUNAL}

\section{S u m mary}

The verdict of the Supreme Court of 11 October 2013 (file I CSK 697/12) and the decision of the Constitutional Tribunal of 25 June 2015 (file SK 32/14) are discussed and their significance for the understanding of punitive damages analysed. The main problem discussed in this paper is the question whether there is room under Polish law for punitive damages modelled a common law system and whether the adoption of this solution could possibly influence the basic premises constituting the liability for damages already adopted.

The main focus has been put on the argumentation of the Supreme Court presented in its verdict regarding the possibility of enforcing by Polish courts a judgment in which a foreign court awarded punitive damages, and the arguments of the Constitutional Tribunal regarding the constitutionality of a legal provision establishing a possibility of flat-rate damages, being awarded and increased in the event of the determination of guilt by the breaching party. Certain detailed provisions that are contradictory from the point of view of the fundamental assumptions underlying the liability for damages in Polish law and the laws of most European legal systems (and the German system in particular) are also examined. Further, a synthetic analysis of the positive and negative aspects of punitive damages identified by other researchers is presented. This is followed by a mention of other institutions available under Polish law which may constitute an alternative to punitive damages, at least when it comes to the provision of an adequate preventive and punitive measure in the event of gross or culpable damage.

Keywords: the law of obligations - liability for damages - punitive damages - the compensatory function of damages 